\title{
Reconstructing the 1874 Santa Tecla flash flood in the Ondara River (Ebro Basin, NE Spain)
}

\author{
J. C. Balasch, J. Tuset, and J. L. Ruiz-Bellet \\ Department of Environmental and Soil Sciences, University of Lleida, Spain
}

Received: 19 February 2010 - Revised: 1 April 2010 - Accepted: 19 May 2010 - Published: 2 July 2010

\begin{abstract}
The Santa Tecla flash flood, a very heavy event occurred in Tàrrega (Catalonia, NE Iberian Peninsula) in 1874, was reconstructed with hydraulic and hydrological modelling tools. The hydrograph obtained in a first stage and the basin soil moisture information ultimately allowed the estimation of the range of the rainstorm magnitude which caused the flash flood. The reconstruction of historical floods has proved useful to improve the flood probability analysis, especially in ungauged basins.
\end{abstract}

\section{Introduction}

The Santa Tecla flood may be considered one of the most catastrophic rainfall and flood events in the modern history of the Western Mediterranean Basin. This event took place during the night between 22nd and 23rd September 1874 (the 23rd being Saint Tecla's day), in which torrential convective rainfalls generated flash floods in most of the small streams in the southern half of Catalonia, NE Iberian Peninsula (i.e. Ondara, Corb, Francolí and Siurana catchments). More than 570 people died, 150 of which in the Ondara River flooding at the town of Tàrrega.

This huge flood took place in the preinstrumental era and, consequently, there are neither precipitation nor flow records; therefore, the event had to be hydraulically and hydrologically reconstructed for the Ondara River at Tàrrega $\left(150 \mathrm{~km}^{2}\right.$ of basin area, Fig. 1) from historical information. Indeed, the maximum water level and the temporal evolution of the flood were obtained, respectively, from several epigraphic limnimarks found at Tàrrega (Fig. 2) and from event descriptions recorded in contemporary documents (Salvadó, 1875; Pleyán de Porta, 1945). Besides, the information from local archaeo-

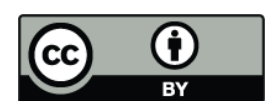

Correspondence to: J. C. Balasch (cbalasch@macs.udl.cat) logical sites allowed the reconstruction of the fluvial sections at Tàrrega at the end of the 19th century (Figs. 3, 4 and 5). Likewise, some old cellars flooded during the event provided information about sediment concentration at the peak-flow time.

\section{Methodology}

The methodology put in practice for the event reconstruction had two stages (Fig. 6). The first stage was the estimation of the peak flow through the iterative application of a hydraulic model. The input data were: a digital terrain model of the river bed (taking into account the three-meter channel infilling caused by the Sant Agustí bridge, according to archaeological data; Fig. 3); the stream, floodplain and urban areas roughness coefficients $(0.035,0.04$, and 0.1 , respectively); the channel slope (0.0045); and a tentative peak flow. The process was iterative, trying different peak flows until the modelled maximum water level was close enough to the one known through the limnimetric marks $(8.84 \mathrm{~m}$ above the 1874 river bed; $5.20 \mathrm{~m}$ above present-day one; Figs. 2 and 4). The hydraulic model used was the unidimensional HEC-RAS (USACE) applied in several cross-sections of the Ondara River at Tàrrega, spaced $40-50 \mathrm{~m}$ in average (Fig. 5).

The second stage was the hydrological modelling, the objective of which was to find the event hyetograph. The process was, once again, iterative, since the searched magnitude was an input instead of an output of the model. Thus, from a tentative hyetograph constructed from the historical descriptions of the event (the 6-8 $\mathrm{h}$ rainfall duration according to Salvadó's account), the basin characteristics (soil type, land use and cover) and the antecedent soil moisture, the runoff or effective rainfall depth was calculated using the Soil Conservation Service's Curve Number method (SCS, 1985). Then, the Synthetic Unit Hydrograph transfer function and a

Published by Copernicus Publications on behalf of the European Geosciences Union. 


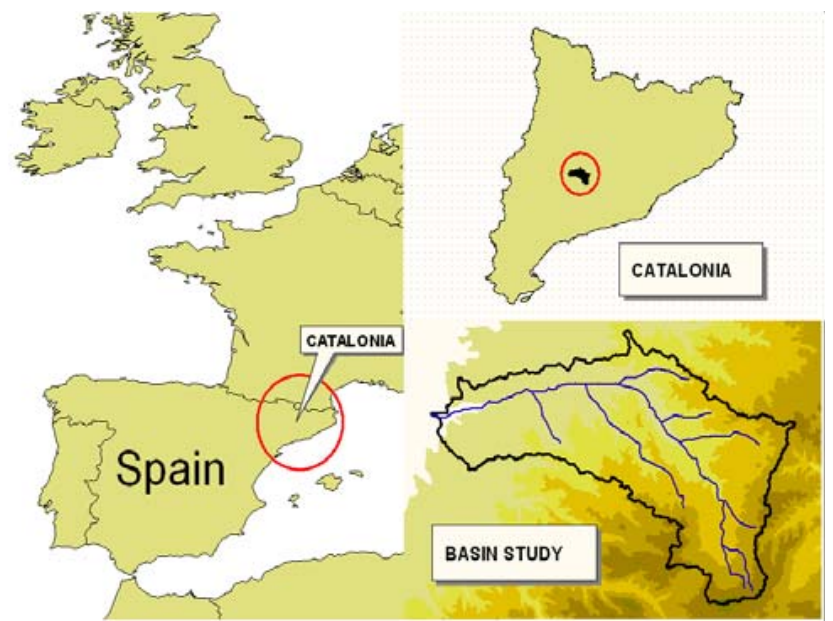

Fig. 1. Map of the Iberian Peninsula with the location of the Ondara basin.

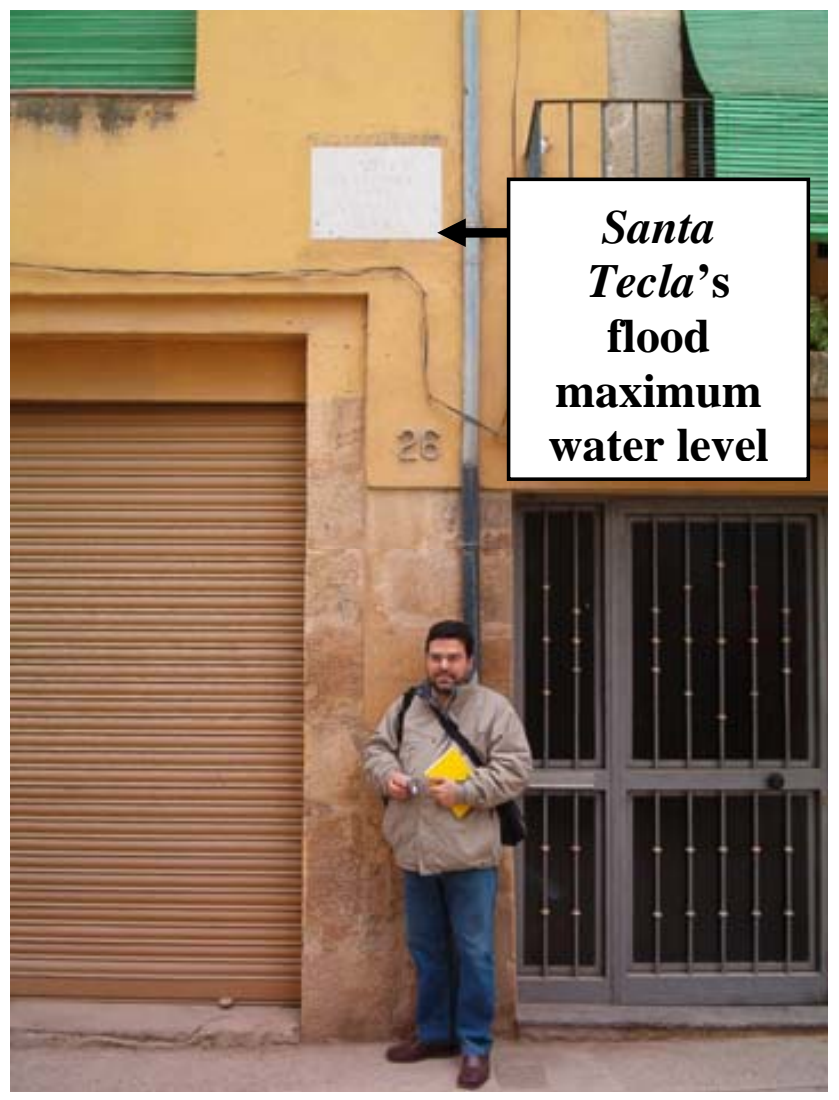

Fig. 2. Epigraphic limnimark at Sant Agustí street (Tàrrega) which indicates the maximum water level reached by the the Santa Tecla flood.

wave propagation method (Muskingum-Cunge) were applied to this runoff value to obtain a convoluted and routed hydrograph. This process was repeated with a new tentative hyetograph until the peak flow of the resulting hydrograph was

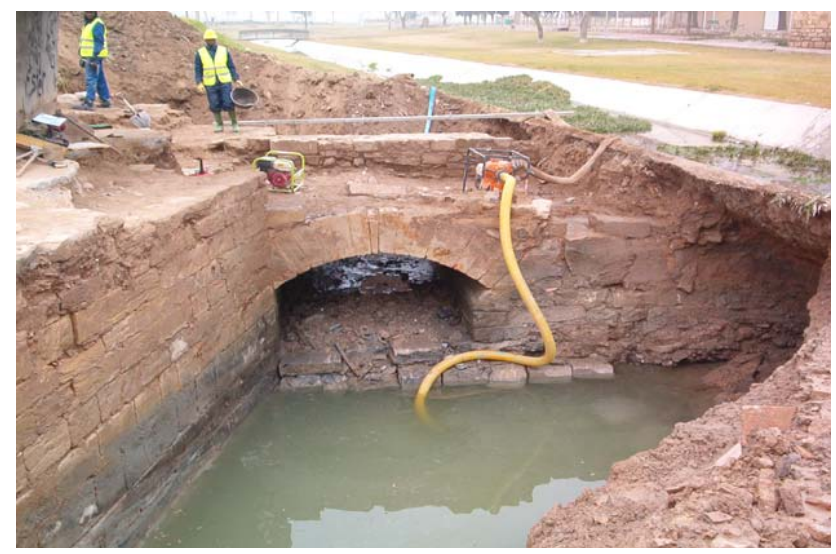

Fig. 3. The Sant Agustí Bridge's remains discovered by an archaeological survey conducted in 2008 .

SUPERIMPOSTIION OF THE CURRENT SECTION IN RELATION WITH THE SECTION OF 1874 OF THE ST. AGUSTISSTREET

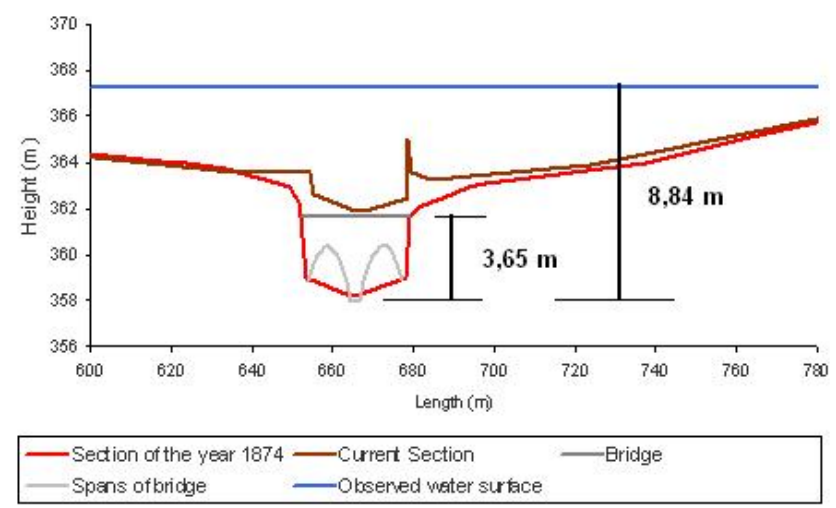

Fig. 4. Present-day (brown line) and 1874 (red line) cross-sections of the Ondara River at Sant Agustí Bridge and the eponymous street with the indication of the maximum water level (blue line) reached by the Santa Tecla flood.

close enough to the one found in the first stage (Fig. 6). The software used in this stage was the HEC-HMS v. 3.3/2008 (USACE).

Once a tentative hyetograph was accepted, its magnitudefrequency relation was assessed through its return period, which was calculated with an extreme value distribution

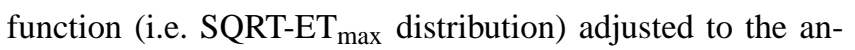
nual 24-h maximum rainfall series of the basin. This series was constructed with a height-area correlation fitted to three rain-gauge data series: a) Tarrega (383 ma.s.1.) at the basin outlet, b) Cervera (540 m a.s.1.), in the center of the basin and c) Santa Coloma de Queralt (680 m a.s.1.), near the headwaters. 


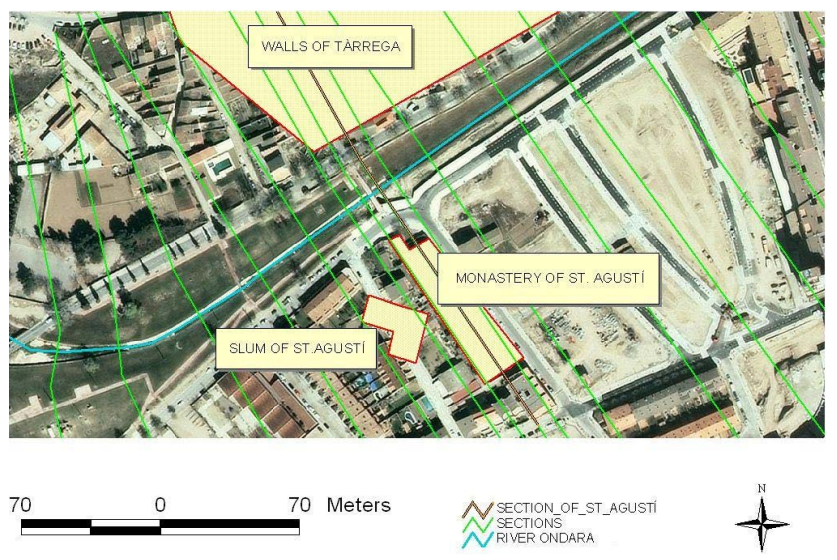

Fig. 5. Aerial photograph of the Ondara river channel (blue line) at Tàrrega with the location of Sant Agustí cross-section (brown line) and the rest of cross-sections (green lines) used in the hydraulic modelling. This figure shows, as well, the alleged location of the external walls of the town and the disappeared Sant Agustí slum and monastery according to the archaeological remains.

\section{Results and discussion}

The results of the hydraulic modelling at the Sant Agustí street cross-section were the following: a) a section-averaged maximum water velocity of $2.93 \mathrm{~m} \mathrm{~s}^{-1}$; b) a peak flow of $983 \mathrm{~m}^{3} \mathrm{~s}^{-1}$ (increased in $508 \mathrm{~m}^{3} \mathrm{~s}^{-1}$ by the Cercavins River downstream Tàrrega); and c) a specific peak discharge of $6.6 \mathrm{~m}^{3} \mathrm{~s}^{-1} \mathrm{~km}^{-2}$.

This value exceeds the maximum specific discharge from both the measured data series $\left(5.4 \mathrm{~m}^{3} \mathrm{~s}^{-1} \mathrm{~km}^{2}\right.$ in the Seco River at Oliete; in López-Bustos, 1981) and the historical data series $\left(6 \mathrm{~m}^{3} \mathrm{~s}^{-1} \mathrm{~km}^{2}\right.$; in Thorndycraft et al., 2006). Moreover, it is greater than the maximum 500-year-returnperiod specific discharge in any other similar-sized watershed in the Ebro basin.

From the information obtained in the flooded cellars, the estimated sediment concentration during the peak flow was $11.2 \%$ (in volume), characteristic of a hyperconcentrated and viscous flow.

The water level reached in the above presented crosssection is partially explained by the discovery of the Sant Agustí Bridge, buried until recently in the river bed, which implies that the past section was larger than the presentday one and that the bridge was a huge hydraulic obstacle (Fig. 3).

The hydrological modelling stage results, which derived from the Curve Number method, varied strongly with the antecedent soil moisture condition chosen (Table 1). Thus, if the low previous soil moisture (condition I) is selected, a total rainfall of $238 \mathrm{~mm}$ with a peak intensity over $105 \mathrm{~mm} \mathrm{~h}^{-1}$ is needed to meet the peak flow. If the intermediate previous soil moisture (condition II) is chosen, a total rainfall of $165 \mathrm{~mm}$ with a peak intensity of $74 \mathrm{~mm} \mathrm{~h}^{-1}$ should

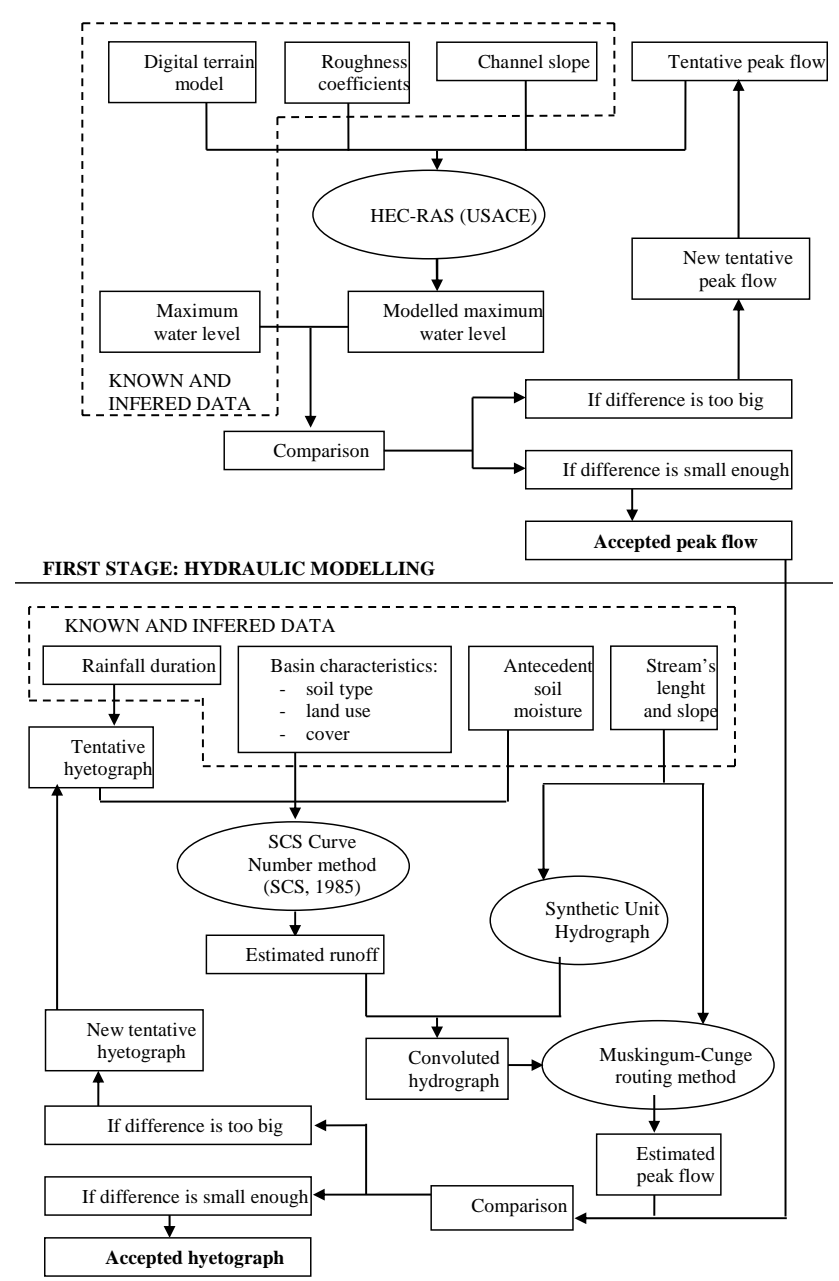

SECOND STAGE: HYDROLOGICAL MODELLING

Fig. 6. Methodological process for the calculation of the event's peak flow and hyetograph.

Table 1. Event's hyetographs summarizing magnitudes (rainfall depth and peak intensity) and their sensitivity to the previous soil moisture condition

\begin{tabular}{lcc}
\hline Antecedent soil moiture & $\begin{array}{l}\text { Rainfall depth } \\
(\mathrm{mm})\end{array}$ & $\begin{array}{l}\text { Peak intensity } \\
\left(\mathrm{mm} \mathrm{h}^{-1}\right)\end{array}$ \\
\hline Dry (condition I) & 238 & 105 \\
Intermediate (condition II) & 165 & 74 \\
Saturated soil (condition III) & 127 & 43 \\
\hline
\end{tabular}

have occurred. And, for a saturated soil (condition III), the most likely scenario according to the contemporary information (Pleyán de Porta, 1945), the event's hyetograph is the one shown in Fig. 7; in this case, the total rainfall would have been $127 \mathrm{~mm}$ with a maximum intensity of $43 \mathrm{~mm} \mathrm{~h}^{-1}$. Other intermediate results linked to this saturated-soil condition hyetograph were a) a surface runoff total volume of 

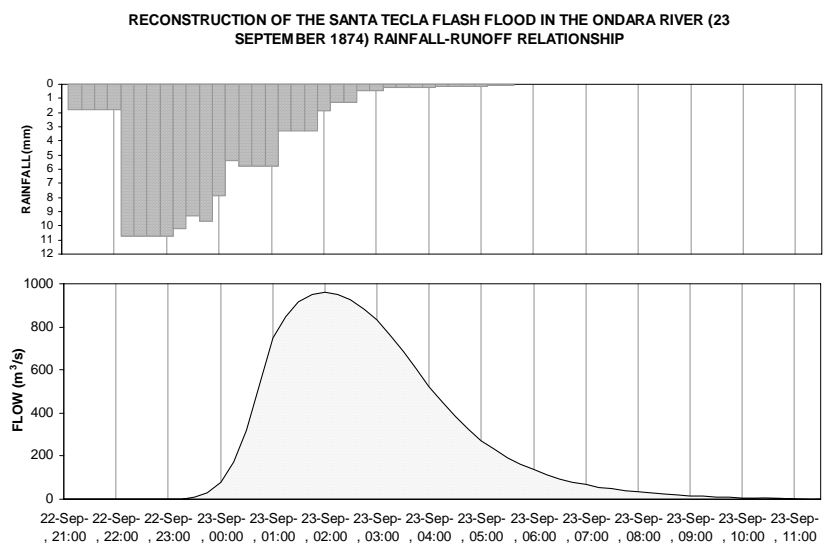

Fig. 7. Accepted hyetograph and its modelled hydrograph after the iterative process for the Santa Tecla flash flood at the Sant Agustí Bridge cross-section (Tàrrega).

$13.1 \mathrm{hm}^{3}$; b) a runoff coefficient of about $35.5 \%$; and c) a lag-time of $3 \mathrm{~h}$.

According to the SQRT-ET max $_{\text {ax }}$ extreme distribution function fitted to the regional systematic data, the rainfall value for the intermediate previous moisture condition (II) had a 1000-year return period and, for a saturated soil (condition III), a 200-year return period.

\section{Conclusions}

The specific peak discharge estimated for the Santa Tecla event is located in the uppermost part of the regional peak discharge of both the systematic database and the historical records; this fact gives a new insight of the extreme events in this Mediterranean area. Indeed, if the Ondara basin soils are in a saturated or in a near-saturated state before a rainstorm, the rainfall depth and the peak intensity don't need to be extraordinary to generate a heavy flash flood.

Contemporary available information of the event (Salvadó, Pleyán de Porta) and archaeological data were crucial for a right reconstruction of the past fluvial sections and the characteristics of the flow, which led to the understanding of both the flood and the rainstorm event which caused it. This highlights that more historical and multidisciplinary studies in this sense are needed to improve the floods reconstruction methods and to reduce their uncertainty level, which unfortunately is not small.
Acknowledgements. The authors thank Michel Lang for his comments, which helped improve the manuscript.

Edited by: M.-C. Llasat

Reviewed by: one anonymous referee

\section{References}

López-Bustos, A.: Tomando el pulso a las grandes crecidas de los ríos peninsulares, Revista de Obras Públicas, 3190, 179-192, 1981.

Pleyán de Porta, J: Efemérides leridanas recogidas y ordenadas, Institut d'Estudis Ilerdencs, Lleida, Spain, 1945.

Salvadó, J.: Memoria de la inundación acaecida en la villa de Tárrega en la madrugada del dia 23 de Setiembre del año 1874, Est. Tip. Ramirez, Barcelona, Spain, 1875.

Soil Conservation Service: Estimation of direct runoff from storm rainfall. Chapter 10. In Hydrology Natl. Eng. Handbook, Suppl. A, Section 4. USDA-SCS, Washington DC, 1985.

Thorndycraft, V., Barriendos, M., Benito, G., Rico, M., and Casas, A.: The catastrophic floods of AD 1617 in Catalonia (northeast Spain) and their climatic context, Hydrol. Sci. J., 51(5), 899-912, 2006. 